\title{
Peranan Komunikasi Interpersonal Antara Guru Bimbingan Konseling (BK) dengan Siswa dalam Menangani Kenakalan Siswa (Studi Kasus di SMP Kristen 2 Salatiga)
}

\author{
Johan Chris Timothius \\ Mahasiswa Jurusan Komunikasi Strategis \\ Magister Ilmu Komunikasi Universitas Diponegoro \\ Email: johanchrist5@gmail.com
}

\begin{abstract}
Communication is one of the most parts in human life. There are several types of communication: interpersonal communication, intrapersonal communication, and mass communication. This study focused on interpersonal communication in education between the teacher and the students. The aim of this study was to know the function of interpersonal communication to solve students' matter at school. The study conducted in SMP Kristen 2 Salatiga, because the school has had face the problems.

The qualitative method was used. Interview and observation were used to collect the data the interview and observation are done with four persons as key respondent: three students and one teacher as counselor. Then, triangulation and content analysis were used to know the respondents' pattern.

The data analysis showed that interpersonal communication gave contribution to solve the students' matter. The teacher himself should be active by using client center and exchange theory to solve the students' problem. Furthermore, if there are some matters between teacher and students or students to students, interpersonal communication is the effective way to solve the problems.
\end{abstract}

Keywords: interpersonal communication, education, students' problem.

\section{Pendahuluan}

Pada hakekatnya, komunikasi merupakan suatucarauntukdimanamanusiamempertahankan hidupnya dan komunikasi interpersonal merupakan salah satu bagian aspek pendukung komunikasi yang penting bagi kehidupan kita. Komunikasi interpersonal mempunyai peran dalam menciptakan kebahagiaan hidup manusia diantaranya; komunikasi interpersonal membantu perkembangan intelektual dan sosial kita, identitas atau jati diri kita terbentuk melalui komunikasi dengan orang lain. Untuk memahami realitas disekeliling kita, kita perlu pengertian orang lain. Kesehatan mental kita sebagian ditentukan oleh kualitas komunikasi dengan orang lain dan agar kita bahagia memerlukan pengakuan dari orang lain (Supratiknya, 1995: 9).

Komunikasi interpersonal bisa terjadi dimana saja, antara lain : dirumah, di sekolah, di masyarakat, di kantor, di Gereja, dan lainlain. Komunikasi interpersonal pada waktu di sekolah, guru merupakan faktor yang penting dalam berkomunikasi dengan siswa. Terlebih halnya, jika terdapat siswa yang mempunyai kenakalan dan membuat guru BK ikut bertindak. Untuk mengatasi masalah tersebut, maka komunikasi interpersonal akan dipergunakan sebagai tolak ukur bagi guru BK dalam menangani masalah-masalah kenakalan siswa, karena sifat dari komunikasi interpersonal yang hanya dipergunakan antarpribadi (dua orang atau lebih), dalam arti antara guru BK dengan siswa. Untuk mengatasi masalah-masalah kenakalan siswa, guru BK pasti akan menggunakan cara yaitu dengan bimbingan konseling.

Siswa-siswa yang bermasalah di sekolah pastiakandituntunolehguruBKdalammenangani masalah-masalah yang dihadapi dengan cara menggunakan komunikasi interpersonal. Disini 
peranan dari guru BK di sekolah sangat penting karena membantu tercapainya tujuan pendidikan nasional dan membantu individu untuk mencapai kesejahteraan dan juga memegang peranan yang besar bagi tumbuh kembang siswa-siswi ke depannya.

Sebuah bimbingan dan konseling di sekolah itu sebenarnya penting bagi seluruh siswa, tidak hanya terbatas kepada siswa-siswi yang bermasalah. Namun, bedanya dengan siswa yang tidak bermasalah yaitu siswa-siswi yang bermasalah harus lebih serius dalam proses bimbingan dan bahkan seorang guru pun masih membutuhkan layanan bimbingan dan konseling. Sebenarnya bimbingan bagi siswa-siswi di sekolah merupakan hal yang wajar, karena pada dasarnya setiap individu berbeda-beda akan karakter, kemampuan, pola pikir, dan persoalan atau masalah-masalah yang mereka hadapi. Pada usia siswa-siswi anak SMP wajib membutuhkan bimbingan dikarenakan siswa-siswi tersebut masih mencari identitas diri, mencari bakat minat, dan kemampuannya yang akan dipergunakan bagi masa depannya (Asmani, 2010: 47).

Dalam penelitian ini, dibahas secara mendalam mengenai komunikasi interpersonal yang terjadi diantara guru Bimbingan Konseling (BK) dengan siswa yang bermasalah yaitu membolos sekolah. Peneliti meneliti siswa SMP (Sekolah Menengah Pertama) yang dijadikan obyek penelitian, yaitu SMP Kristen 2 Salatiga. Peneliti menetapkan SMP Kristen 2 Salatiga tersebut untuk dijadikan obyek penelitian dikarenakan dengan alasan siswa-siswi SMP tersebut masih dapat dikatakan nakal dan masih membutuhkan proses bimbingan dari para guru terlebih dari guru Bimbingan dan Konseling (BK). Kenakalan siswa yang dimaksudkan oleh peneliti yaitu siswa-siswinya yang membolos sekolah. Peneliti memilih masalah tersebut karena masalah membolos sekolah merupakan masalah yang dominan atau sering terjadi di SMP Kristen 2 Salatiga. Melalui berbagai uraian tersebut maka didapatlah rumusan masalah yang menjadi fokus dalam penelitian ini, yaitu "Bagaimana peranan komunikasi interpersonal antara guru BK dengan siswa dalam menangani masalah siswa yang membolos sekolah di SMP Kristen 2 Salatiga?"

Berikut adalah merupakan bagan kerangka penelitian dalam komunikasi interpersonal antara guru dengan siswa-siswinya.

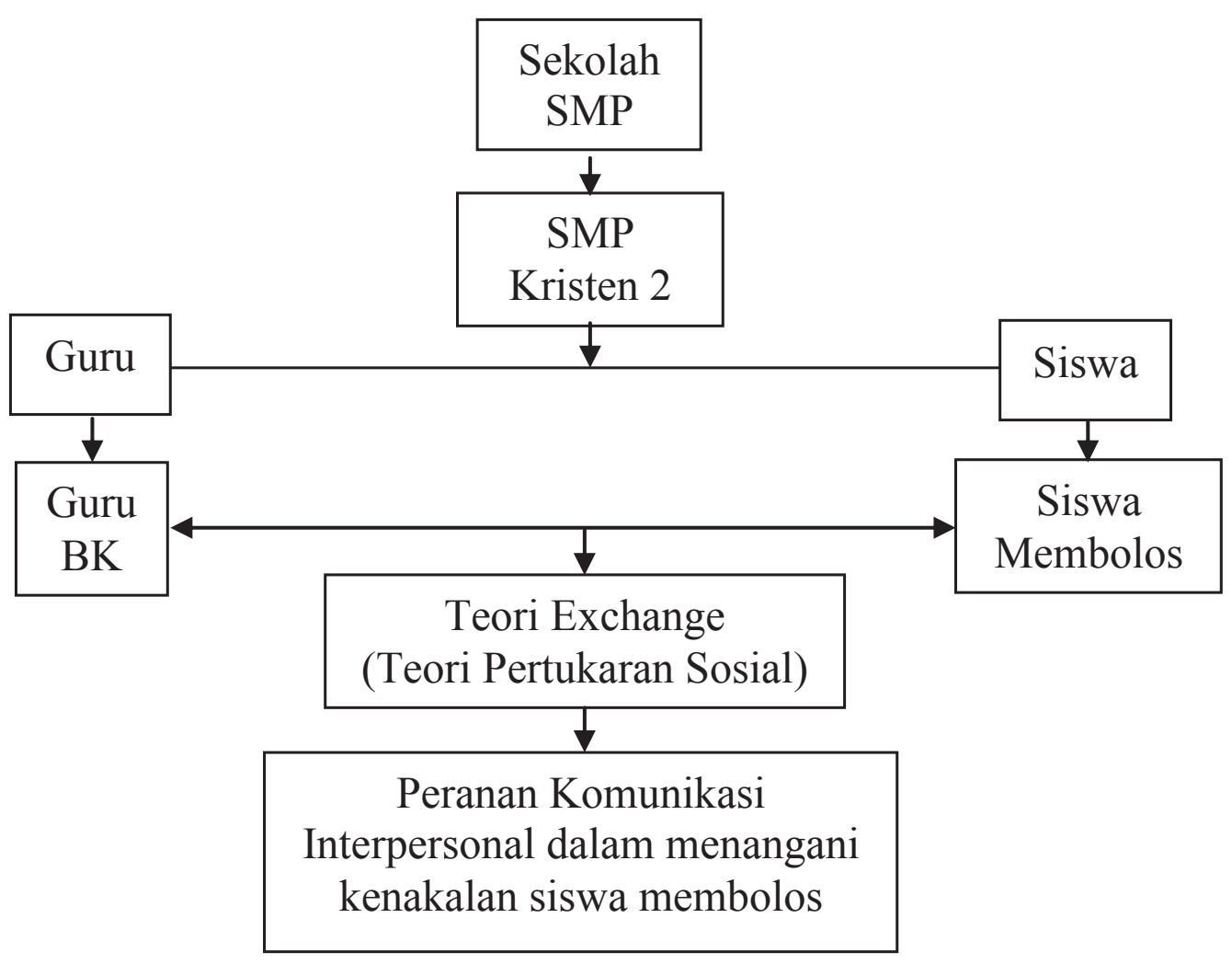




\section{Metoda Penelitian}

Penelitian ini dikategorikan ke dalam bentuk jenis penelitian deskriptif dengan pendekatan kualitatif yang bertujuan untuk menguraikan sifat atau karakteristik dari suatu fenomena tertentu.

Dalam penelitian ini, metode pengumpulan data yang dipergunakan adalah dengan mempergunakan teknik wawancara yang merupakan salah satu metode untuk mendapatkan data tentang individu dengan mengadakan hubungan secara langsung dengan informan (face to face relation). Informan yang dimaksud dalam penelitian ini guna mendapatkan datadata yang diperlukan dari para nara sumber yang terkait yaitu antara lain:

Utami, Guru Bimbingan Konseling SMP Kristen 2 Salatiga.Gerald, siswa kelas 7 SMP Kristen 2 Salatiga. Lia, siswi kelas 8 SMP Kristen 2 Salatiga.Ade, siswa kelas 9 SMP Kristen 2 Salatiga.

Peneliti juga melakukan observasi di lapangan dan mengikuti saat terjadinya proses konseling berlangsung. Peneliti hanya melihat, mengamati mulai dari siswa-siswi yang membolos di panggil satu persatu oleh guru BK dan menghadap ke ruang konseling. Semua kegiatan itu peneliti amati dengan menggunakan alat indera dan peneliti dokumentasikan dalam bentuk hasil foto. Selain itu, peneliti juga mengumpulkan data-data sekunder yang di dapat melalui buku atau referensi-referensi (buku tentang komunikasi; buku tentang komunikasi interpersonal; buku tentang bimbingan dan konseling; jurnal komunikasi; serta artikel-artikel di internet yang berkaitan dengan komunikasi, komunikasi interpersonal, bimbingan konseling, dan kenakalan siswa).

\section{Tinjauan Pustaka}

Teori dan ciri yang mendukung komunikasi interpersonal dalam penelitian ini adalah sebagai berikut:

i. Teori Exchange (Teori Pertukaran Sosial) menurut Schramm (dalam Susanto, 1974:
41):

Model ini memandang hubungan interpersonal sebagai suatu transaksi dagang. Setiap individu dengan secara sukarela memasuki dan tinggal dalam hubungan sosial hanya selama hubungan tersebut cukup memuaskan ditinjau dari segi ganjaran, biaya, pengorbanan, dan keuntungan yang saling mempengaruhi. Model ini berpendapat bahwa orang melakukan suatu hubungan interpersonal karena membutuhkan orang lain dan mengharapkan sesuatu untuk memenuhi kebutuhannya, karena pada dasarnya manusia adalah makhluk sosial sehingga tidak mungkin dia akan berdiri sendiri tanpa adanya hubungan dengan orang lain. Seseorang akan secara sukarela melakukan hubungan sosial, apabila hubungan tersebut cukup memuaskan dan memberikan manfaat pada dirinya.

ii. Ciri-ciri komunikasi interpersonal dipergunakan peneliti dalam penelitian yang dipergunakan untuk membantu dan memperjelas penelitian yang dikemukakan oleh Rogers (dalam Liliweri, 1997: 13) di antara lain:

a. Arus pesan cenderung dua arah

Jumlah orang yang terlibat dalam komunikasi interpersonal adalah dua orang atau lebih, ketik dua orang bercakap-cakap da percakapan tersebut bertambah semakin serius maka yang tampak adalah percapakan yang bersifat dialogis dan sulit menentukan siapa yang bertindak sebagai komunikan atau komunikator. Ini merupakan cirri komunikasi interpersonal yang proses pengiriman pesan dan umpan balik berlangsung dua arah, berbalasbalasan, dan berganti-gantian secara sinambungan.

b. Mengakibatkan dampak yang disengaja dan tidak disengaja

Komunikasi interpersonal sering mengibatkan suatu hasil yang 
direncanakan maupun yang tidak direncanakan terlebih dahulu.

c. Mempersyaratkan hubungan paling sedikit dua orang dengan hubungan yang bebas dan bervariasi, ada keterpengaruhan

Faktor kedekatan biasanya menyatakan dua orang yang mempunyai hubungan yang erat. Kedekatan interpersonal mengakibatkan seseorang bisa dan mampu menyatakan pendapatpendapatnya dengan bebas dan terbuka. Kebebasan dan keterbukaan akan mempengaruhi berbagai variasi pesan baik verbal maupun nonverbal. Suasana yang bebas dan terbuka tanpa hambatan psikologi maka komunikator dan komunikan interpersonal bisa menyatakan pikiran perasaan, dan tindakan yang bervariasi.

d. Harus membuahkan hasil

Komunikasi interpersonal dikatakan sukses jika komunikasi tersebut menghasilkan sesuatu yang diharapkan, hasilnya harus nyata, nyata dalam mengubah wawasan, perasaan, maupun perilaku.

\section{Analisis dan Pembahasan}

Sebelum membahas lebih lanjut, perlu diketahui bahwa di sekolah SMP Kristen 2 Salatiga memiliki siswa-siswi yang bermasalah dan tergolong melanggar dari peraturan yang telah ditetapkan. Bagi siswa yang tidak mentaati peraturan (membolos sekolah) dikenakan peringatan dan harus menghadap guru BK untuk melakukan konseling yang dilakukan dengan model tertutup (hanya di antara guru BK dengan siswa yang bersangkutan dan tidak melibatkan orang lain) sehingga terdapat asas kerahasiaan yang terjamin. Darihasilobservasi, saatterjadinya proses konseling didapatkan bahwa peneliti menemukan cara (treatment) yang dilakukan oleh guru BK dengan membuat siswa-siswinya merasa senyaman mungkin untuk di wawancarai atau diintrogasi tentang permasalahan yang dialami. Selain itu, ada pendekatan yang dilakukan guru BK yaitu pendekatan klien center. Setiap siswanya diminta untuk menyadari kesalahannya, kemudian mencari dan mencoba menemukan solusi agar permasalahan yang dialami tidak terulang kembali. Disini akan terlihat peranan dari komunikasi interpersonal dalam menyelesaikan sebuah permasalahan dan komunikasi interpersonal yang dilakukan secara dua arah.

Sekolah SMP Kristen 2 merupakan sekolah Swasta yang notabene berbeda dengan sekolah Negeri. Dikatakan berbeda, karena pada sekolah ini adanya sebuah hubungan kedekatakan yang dibangun di antara guru dengan murid, dengan kata lain siswa dapat "leluasa" untuk sharing dengan guru mereka, baik dalam masalah akademik maupun non akademik dan hal ini berbanding terbalik dengan sekolah-sekolahSMP Negeri. Untuk membatasi topik dari penelitian ini, peneliti hanya berfokus kepada siswa-siswi yang bermasalah dalam hal membolos sekolah dengan menggunakan peranan dari komunikasi interpersonal ditambah dengan pendekatan teori pertukaran sosial (Exchange) menurut Schramm (dalam Susanto, 1974: 41). Schramm menjelaskan ketika melakukan suatu hubungan atau komunikasi interpersonal, setiap individu melakukannya dengan tujuan agar mendapatkan hasil yang diinginkan atau memperoleh keuntungan, kepuasan, dan manfaat bagi dirinya pribadi. Jika dalam suatu hubungan komunikasi interpersonal terdapat dua belah pihak yang melakukan hal tersebut atau sama-sama mencari keuntungan dalam berkomunikasi, maka kedua orang tersebut sudah dapat dikatakan mempergunakan teori ini.

Dalam praktik dan kenyataannya, kedua belah pihak melakukan hubungan komunikasi (konseling) yang bertujuan untuk mencari keutungan bagi dirinya sendiri. Disatu sisi, keuntungan melakukan hubungan komunikasi (konseling) bagi guru BK yaitu dapat lebih mengenali, mengetahui mengenai karakter, sifat, perilaku dari para siswa atau klienkliennya mengapa sampai mengambil keputusan membolos sekolah. Disisi lain, keuntungan 
bagi para siswa-siswinya yaitu mereka bisa mengetahui tentang permasalahan yang sedang dihadapi, mereka bisa menilai tentang kesalahan yang mereka perbuat dan diharapkan selanjutnya mereka bisa mengambil jalan keluar sendiri (keputusan terbaik) agar tidak melakukan kesalahan kembali yaitu membolos sekolah.

Dua masalah yang dominan terjadi di SMP Kristen 2 Salatiga menurut hasil survey peneliti dilapangan dan hasil pernyataan dari guru BK didapatkan masalah tersebut adalah prestasi rendah (nilai jelek) dan masuk tanpa ada keterangan atau membolos sekolah. Jika masalah membolos, guru BK akan secara langsung menangani masalah tersebut dan tidak segansegan untuk melakukan inspeksi mendadak.

Dalam proses penanganan siswa yang membolos, guru BK akan turun tangan dalam mengatasi persoalan tersebut. Guru BK akan melakukan proses konseling secara nyaman terhadap anak yang membolos tersebut kemudian akan dianalisa sesuai dengan situasi dan kondisi yang terjadi pada saat itu dimana di dalam komunikasi interpersonal, satu orang berhubungan dengan orang lain karena mengharapkan sesuatu untuk memenuhi kebutuhannya. Selain merupakan tugas dan kewajiban dari seorang guru BK, Ia mengharapkan agar masalah yang dialami oleh anak asuhnya dapat segera tuntas kemudian agar prestasi belajar atau nilai dapat meningkat, dan akan sering untuk masuk sekolah, seperti penjelasan Utami, selaku sebagai guru konseling di SMP Kristen 2 Salatiga:

"Kalau melihat akar persoalannya dia tidak mau sekolah, mungkin karena merasa tersinggung dengan guru atau karena punya masalah keluarga atau dia merasa tertekan dalam mengikuti pelajaran. Sedangkan contoh dalam menangani masalah anak membolos, saya akan melihat dari situasi kondisinya. Biasanya anak itu akan tahu kalau anak itu membolos dan guru pembimbingnya tahu pasti akan di panggil dan akan ditanya. Dan yang saya lakukan, saya buat anak itu nyaman untuk bercerita mengapa dia mengambil keputusan untuk membolos. Nah dari cerita itu, kemudian akan dianalisa apakah dari diri sendiri atau lingkungan atau keluarga dan kemudian baru melakukan konseling”.

Perlu diketahui, secara langsung komunikasi interpersonal berperan serta membantu guru BK dalam melakukan proses konseling karena sesuai dengan ciri komunikasi interpersonal yakni; adanya arus pesan yang cenderung dua arah, mempersyaratkan hubungan paling sedikit dua orang dengan hubungan yang bebas dan bervariasi dan ada keterpengaruhan, dan kemudian harus membuahkan hasil. Ciriciri tersebut juga secara langsung membantu proses konseling. Utami menjelaskan,

"Dalam hal ini memang komunikasi yang dilakukan itu komunikasi interpersonal. Jadi, bagaimana saya selaku guru pembimbing membangun komunikasi ini sehingga ada komunikasi timbal balik dan anak juga sangat merasa diuntungkan, dan guru pembimbing juga merasa dapat membantu anak yang sedang menghadapi masalah".

Pendekatan yang dilakukan oleh guru BK adalah pendekatan klien center. Setiap para nara sumber diminta untuk menyadari bahwa dia bersalah, kemudian mencari dan mencoba menemukan langkah atau solusi yang tepat agar persoalan yang dialami yaitu masalah membolos dapat tidak terjadi atau terulang kembali. Disini peneliti menggaris bawahi, jika peranan dari komunikasi interpersonal sangat penting dalam membantu serta menyelesaikan sebuah masalah yang dialami oleh siswa yang membolos, seperti pernyataan Utami yang menceritakan,

"Nah, kalo misalnya melakukan
pendekatan konseling dengan
melakukan klien center jadi pusat
dari persoalan itu adalah ada di
anak, sehingga dia betul-betul harus
bisa mampu menyadari bahwa dia


sedang bermasalah dan kemudian

setelah dia menyadari bagaimana

langkah penyelesainya. Nah disitulah

komunikasi itu sangat penting".

Peneliti menemukan bahwa Guru BK berjuang semaksimal mungkin untuk para siswa-siswinya terutama bagi mereka yang bermasalah dalam hal membolos. Berdasarkan pada pengamatan yang dilakukan, konselor memberikan sebuah harapan baru dengan harapan para siswa-siswi yang bermasalah tersebut tidak mengulangi kembali kesalahan yang sama.

Pada saat melakukan proses konseling, ada pula penilaian evaluasi yaitu penilaian proses maupun penilaian hasil. Dalam penilaian hasil juga dibagi menjadi tiga bagian penilaian; pertama penilaian jangka panjang, kedua penilaian jangka pendek, dan ketiga penilaian segera. Sewaktu guru BK melakukan konseling, guru BK mengambil contoh dengan menggunakan penilaian segera untuk menilai apakah proses konseling baik proses komunikasi yang dilakukan sudah menyentuh dengan permasalahnya apa belum? Apakah juga ada komunikasi interpersonalnya? Jika penilaian jangka pendek diberikan waktu seminggu setelah konseling dilakukan, sedangkan jika penilaian jangka panjang diberikan waktu satu bulan setelah dilakukannya proses konseling.

Nara sumber 1 yaitu Gerald merupakan siswa kelas 7 yang tergolong sering membolos sekolah atau sering tidak masuk tanpa keterangan. Siswa ini sering bertemu dengan guru BK untuk melakukan konsultasi atau sering melakukan konseling dengan guru konselingnya dan tidak merasa takut untuk bertemu dengan guru BK seperti menurut pernyataannya berikut,

"Kalau di sekolah itu sering ketemu sama Bu Tami, saya tidak takut ketemu dengan Beliau karena Bu Tami membantu untuk menyemangati belajar agar nilainya bisa baik”.

Dalam proses konseling tersebut, nara sumber 1 bercerita mengenai pelajaran di sekolah dan mengenai masalah intern yaitu masalah keluarga dirumah. Nara sumber 1 melakukan hubungan atau interaksi dengan guru konselingnya dikarenakan nara sumber 1 ingin terlepas dari masalah yang mengikatnya hingga sampai berhubungan langsung dengan guru BK-nya. Pada saat melakukan konseling, terkadang nara sumber 1 berkonsultasi sendiri maupun dengan para teman-temannya.

Nara sumber 2 yaitu Lia merupakan siswi yang memiliki banyak masalah baik di sekolah maupun dirumah, yang membuat dampak dan berpengaruh terhadap prestasi atau nilai jelek. Nara sumber 2 merupakan siswi kelas 8 yang sering di panggil oleh guru BK untuk menghadap dan berkonsultasi mengenai perilakunya di sekolah yang sering membolos dan perilakunya yang sering kabur dari rumah. Dalam melakukan proses konseling, biasanya di panggil oleh guru BK untuk menghadap dan membicarakan mengenai masalah membolos sekolah sampai kepada masalah mengenai nilai-nilai yang menurun yang dijelaskan dalam pernyataan berikut,

"Perasaannya sering di panggil ya

kadang jengkel soalnya malu sama temen kok di panggil terus, kadang juga jengkel sama Bu Tami”.

Selanjutnya, nara sumber 3 dalam penelitian ini adalah Ade yang merupakan siswa kelas 9 dan paling besar di antara nara sumber lainnya. Ade merupakan salah satu siswa yang tergolong berani mengambil keputusan untuk membolos sekolah. Nara sumber 3 dibantu untuk keluar dari permasalahan atau persoalan yang dialaminya agar ke depannya tidak mengulangi kesalahan yang sama yaitu membolos sekolah. Dukungan moril yang dilakukan oleh guru BK berhasil membuat nara sumber 3 untuk bersemangat kembali didalam bersekolah dan dalam studinya. Dan inilah hasil wawancara yang didapat peneliti saat nara sumber 3 tidak mengulangi pelanggarannya di sekolah yaitu membolos sekolah.

\section{"Waktu saya ditemui sama Bu Tami untungnya banyak sekali. Saya jadi rajin sekolah, belajar tekun, tidak}


sering membolos lagi”.

Nara sumber 3 melakukan proses konsultasi dengan guru BK dengan harapan agar segera terbebas dari masalah yang menimpanya. Ade menginginkan agar cepat keluar dari masalah tersebut, maka dari itu dengan secara sukarela nara sumber 3 mau untuk menjelaskan kepada Ibu Utami mengenai permasalahan yang membuat dia mengambil keputusan untuk membolos sekolah. Penjelasan hasil wawancara tersebut seperti demikian,

"Dulu semester satu saya sering membolos karena ketakutan waktu pelajaran matematika. Saya membolos karena sering tidak mengerjakan tugas".

Seperti pendapat (Schramm dalam Susanto, 1974: 41) dalam teorinya yang mengungkapkan, "Seseorang akan secara sukarela melakukan hubungan sosial, apabila hubungan tersebut cukup memuaskan dan memberikan manfaat pada dirinya". Inilah yang menjadi alasan dari ketiga nara sumber yang menginginkan dapat segera menyelesaikan persoalannya mengenai masalah membolos dan itu memberikan manfaat yang sangat tidak berguna (sia-sia) bagi dirinya sendiri.

Penelitian di atas dapat terlihat bahwa proses konseling merupakan sebuah proses yang penting bagi siswa-siswi yang bermasalah di sekolah sepertinya misalnya membolos sekolah. Setiap anak (para nara sumber) membutuhkan bimbingan dari setiap guru pada umumnya (saat anak tersebut berada di sekolah) dan bimbingan dari para orang tua (saat anak tersebut berada dirumah). Tanpa adanya unsur ikut campur dari kedua pihak (guru dan orang tua) tersebut dirasakanoleh peneliti sangatsulituntukmendidik anak atau siswa-siswi agar menjadi seperti apa yang diharapkan baik bagi orang lain maupun bagi dirinya sendiri, karena saat-saat usia seperti anak SMP tersebut harus membutuhkan banyakbanyak perhatian, bimbingan yang sangat ekstra dari para keluarga, kerabat, lingkungan, dan para guru saat di sekolah.

Tindakan-tindakan yang dilakukan guru konselingnya pun pada saat konseling berlangsung, sangat membuat siswanya merasa nyaman sehingga siswa tersebut dapat bercerita mengenai masalah yang sedang dihadapinya dan pada akhirnya membuat dia memutuskan untuk membolos dari sekolah. Seperti pernyataan Utami, selaku Guru BK di SMP Kristen 2 Salatiga,
"Saya membuat anak itu nyaman dengan ada hubungan report, sehingga dia tidak merasa diadili, tidak merasa jadi terdakwa, tidak merasa dihakimi. Nah, kalau sudah suasana rasa nyaman ini terbentuk, ada hubungan yang sudah betul-betul nyaman baru saya melakukan pendekatan konseling dengan melihat karakterik siswa karena setiap individu punya keunikan".

Setelah ketiga nara sumber merasakan kenyamanan saat konseling dilakukan, maka pada saat itu pendekatan klien center dipergunakan oleh guru BK untuk menyelesaikan persoalan atau masalah yang dihadapi oleh siswa. Sesuai dengan pernyataan Utami berikut ini, hasil wawancara yang menjelaskan tentang pendekatan yang berpusat pada anak.

\section{"Ada pendekatan-pendekatan dalam konseling; itu bisa menggunakan klien center, bisa melakukan pendekatan lewat edler. Kalau misalnya melakukan pendekatan konseling dengan melakukan klien center, jadi pusat dari persoalan itu adalah ada di anak, sehingga dia betul-betul harus bisa mampu menyadari bahwa dia sedang bermasalah dan kemudian setelah dia menyadari bagaimana langkah penyelesainya".}

Selain itu, berdasarkan hasil observasi yang telah dilakukan, peneliti melihat bahwa peranan dari komunikasi interpersonal yang dilakukan antara guru BK dengan ketiga nara sumber merupakan komunikasi yang berlangsung secara efektif. Kedua belah pihak saling berinteraksi atau berhubungan dengan baik dalam sebuah 
interaksi atau percakapan. Dalam waktu beberapa bulan ke depan, siswa-siswi tersebut akan secara intensif dilihat perkembangannya oleh guru BK dikarenakan akan menghadapi ujian. Yang terpenting, ketiga nara sumber tidak lagi mengulangi kesalahannya kembali yaitu membolos sekolah. Jelas terlihat, komunikasi interpersonal yang mereka lakukan diantara satu sama lain baik serta dapat menjadi saluran untuk memecahkan masalah yang dialami oleh ketiga nara sumber. Selain itu, keikutsertaan dari teori pertukaran sosial (Schramm dalam Susanto, 1974: 41); dimana satu belah pihak tidak ada yang dirugikan karena sama-sama saling menguntungkan. Satu sisi, ketiga nara sumber membutuhkan seorang konselor yaitu guru BK dan begitu pula sebaliknya. Peneliti juga melihat peranan dari seorang konselor yang sangat membantu siswanya dalam memecahkan suatu masalah atau dalam memberikan sebuah solusi pemecahan dengan cara memberi dukungan secara moril di sekolahan, di mana hal tersebut sangat dibutuhkan bagi setiap para siswa-siswi di sekolah, baik itu yang bermasalah seperti ketiga nara sumber tersebut maupun yang tidak bermasalah.

Peneliti menilai bahwa apa pun yang terjadi pada saat konseling merupakan hasil akhir yang diambil secara dua belah pihak, baik dari sudut pandang guru BK (konselor) maupun dari sudut pandang siswa-siswi yang bermasalah. Seorang guru berperanan atau bertugas sebagai fasilitator dan pembimbing bagi siswa-siswinya di sekolah. Semua keputusan tindakan yang diambil merupakan hasil buah pikir dari kedua belah pihak.

Perkembangan terakhir mengenai siswasiswi tersebut setelah dilakukannya penelitian, siswa-siswi itu menjadi anak yang rajin kembali untuk belajar di sekolah dengan bantuan guru BK saat dilakukannya konseling. Kini setiap dari nara sumber menjadi siswa-siswi yang baik, rajin, dan tekun sesuai dengan yang diharapkan para pengajar dan peneliti menemukannya saat terakhir kali melakukan observasi di lapangan untuk melihat apakah ada hasil yang didapatkan setelah proses konseling yang selama ini dilakukan dengan guru konselingnya.

\section{Penutup \\ Kesimpulan}

Komunikasi interpersonal yang dipergunakan antara guru BK dengan siswa dalam menangani masalah siswa yang membolos sekolah merupakan komunikasi yang efektif bagi kedua belah pihak saat dilakukannya proses konseling, karena komunikasi interpersonal sangat berperan penting dan sangat berpengaruh guna membantu proses konseling tersebut. Komunikasi interpersonal yang dipergunakan saat konseling hanya sebatas komunikasi yang berperan sebagai perantara, sarana, atau penghubung dari interaksi yang dilakukan antara guru BK dengan siswa-siswinya tersebut juga berguna untuk mempertemukan pemikiranpemikiran dari kedua belah pihak. Ditambah dengan dipergunakannya teori Pertukaran Sosial (Exchange) sebagai pemecah permasalahan yang dihadapi guru BK dengan siswa-siswinya yaitu masalah siswa membolos sekolah, sehingga memunculkan timbal balik atau respon dari masing-masing kedua belah pihak. Di samping itu, saat melakukan konseling, komunikasi interpersonal yang dilakukan termasuk kedalam jenis komunikasi terbuka (kedua belah pihak dapat saling jujur) antara guru BK dengan siswa (kliennya). Jadi, hasil akhir dari konseling akan baik untuk pihak guru BK mau pun pihak siswa-siswi yang sama-sama saling diuntungkan antara satu dengan yang lain (simbiosis mutuaslime), sesuai dengan peranan dari komunikasi interpersonal dan ciri-ciri komunikasi interpersonal dengan bantuan teori Exchange menurut Schramm (1974).

\section{Saran}

Berdasarkan penelitian ini, peneliti dapat memberikan beberapa saran untuk Guru BK dan siswa-siswi SMP Kristen 2 Salatiga, diantara lain :

a. Guru BK dapat lebih memperdalam saat 
menggunakan komunikasi interpersonal karena komunikasi ini berperan penting dan sangat membantu dalam menyelesaikan suatu persoalan, juga agar ke depannya nanti guru BK dapat lebih memahami siswa-siswi atau klien-kliennya yang sedang dibantu dalam memecahkan permasalahannya.

b. Guru BK dapat lebih mengerti akan teori-teori dari komunikasi interpersonal agar lebih dapat efektif saat menghadapi permasalahan-permasalahan yang sedang dihadapi oleh para siswa maupun siswinya.

c. Bagi siswa dapat lebih mengenal, memahami, dan mengerti akan peran serta dari komunikasi interpersonal saat menangani permasalahan yang sedang dihadapi.

d. Siswa dapat lebih terbuka (jujur) saat dilakukannya proses konseling dengan mempergunakan komunikasi interpersonal sebagai perantara kepada guru BK, karena pada saat berlangsungnya konseling hanya dilakukan oleh dua orang dan akan terjamin kerahasiaannya sesuai dengan kode etikkode etik yang sudah mengaturnya.

Di samping itu, peneliti juga menyarankan topik pembahasan-pembahasan lain bagi penelitian yang akan datang, yaitu: tetap membahas tentang komunikasi interpersonal, namun ruang lingkup yang berbeda, misalnya komunikasi interpersonal yang digunakan guru untuk meningkatkan minat belajar siswa; komunikasi antara guide dengan turis asing; komunikasi intrapersonal dengan banyak pihak, lalu ada komunikasi kelompok, komunikasi massa, dan lain sebagainya.

\section{Daftar Pustaka}

\section{Buku}

Asmani, Ma'mur, Jamal. (2011). “Tips Efektif Pemanfaatan Teknologi Informasai dan Komunikasi dalam Dunia Pendidikan. Jogjakarta: Diva Press.

Liliweri, Alo. (1997). "Komunikasi Antarpribadi”. Bandung: Cirta Aditya Bakti.

Supratiknya, A. (1995). "Komunikasi Antarpribadi: Tinjauan Psikologis”. Yogyakarta: Kanisius.

Susanto, S., Astrid. (1974). "Komunikasi dalam Teori dan Praktek”. Bandung: Penerbit Bina Cipta.

\section{Jurnal}

Palupi, Yulia Budi. "Jenis dan faktor-faktor penyebab kenakalan siswa tahun pelajaran 2002-2003 (studi kasus di SLTP Negeri 2 Salatiga)". FKIPPPKN., Skripsi., Universitas Kristen Satya Wacana, 2004.

Helensia, Darlena. "Peranan Komunikasi Interpersonal Guru BK (Bimbingan Konseling) dalam mengurangi kenakalan siswa di Bengkulu" (Studi Pada SMK S4 PGRI Kota Bengkulu). Skripsi., Universitas Bengkulu, 2009. 